\title{
Evaluasi Kinerja Tenaga Kerja Bagian Sortasi Biji Pinang (Areca catechu, L.) CV. ABC Berdasarkan Faktor-Faktor yang Berpengaruh
}

\author{
Fikri Arsil ${ }^{1}$, Santosa ${ }^{2}$ \\ ${ }^{1}$ Program Studi Teknik Industri Agro, Politeknik ATI Padang, Bungo Pasang, Tabing-Padang Padang 25171, Indonesia \\ ${ }^{2}$ Program Studi Teknik Pertanian, Universitas Andalas, Limau Manis, Padang 25166, Indonesia
}

\section{ARTICLE INFORMATION}

Received: June 06, 2020

Revised: June 22, 2020

Accepted: June 27, 2020

\section{KEYWORD}

Labors productivity,

Sorting,

Areca nuts,

Doubled linear regression,

Recommendation

\section{CORRESPONDENCE}

Name: Fikri Arsil

E-mail: fikriarsil.gan@gmail.com

\begin{abstract}
A B S T R A C T
Evaluation of influential factors to labors productivity will get the recommendation on human resource development and increase labors performance by company. The aim of this research to know about the effect on motivation, working environmental, salary, working responbility, and lifespan ofareca nuts sorting labors in $\mathrm{CV}$. ABC based on influental factors. The research uses survey method and doubled linear regression analysis for data processing. The result shows that motivation, working environmental, salary, working responbility, and lifespan have effect on sorting labors in CV. $\mathrm{ABC}$ with doubled linear regression analysis is $\mathrm{Y}=-4,640+0,210 \mathrm{X} 1+$ $0,089 \mathrm{X} 2+0,080 \mathrm{X} 3-0,070 \mathrm{X} 4+0,813 \mathrm{X} 5$. This equality shows coefficient value from lifespan variable is biggest, it is 0,813 . Thus, evaluation to sorting labors get 5 recommendations for increasing labors performance.
\end{abstract}

\section{PENDAHULUAN}

Sumatera Barat dikenal sebagai salah satu daerah produktif penghasil komoditi hasil rempah bumi. Salah satu primadona (unggulan) komoditi ekspor adalah biji pinang. Jumlah produksi pinang Sumbar tahun 2014 adalah 42.201 ton [1]. Tanaman Pinang sudah menjadi komoditi perdagangan ekspor dari Indonesia yang diarahkan ke negara-negara Asia Selatan seperti India, Pakistan, Bangladesh, atau Nepal. Negara-negara pengekspor pinang utama adalah Indonesia, Thailand, Malaysia, Singapura, dan Myanmar. Adapun biji pinang yang diperdagangkan terutama adalah yang telah dikeringkan, dalam keadaan utuh (bulat) atau dibelah. Di negara-negara importir tersebut biji pinang diolah menjadi semacam permen sebagai makanan kecil. Sehingga bisa disimpulkan tanaman pinang merupakan komoditi perkebunan yang memiliki peran sebagai sumber devisa negara dan sumber pendapatan bagi petani. Sebuah Perusahaan Hasil Rempah Bumi menjadikan Pinang sebagai komoditi unggulan. CV. $\mathrm{ABC}$ secara konsisten mengekspor 100 ton/bln biji pinang belah [2] CV. ABC juga mengekspor berbagai macam hasil rempah lainnya seperti kayu manis (100 ton/bulan), damar batu (100 ton/bulan), biji coklat (80 ton/bulan), gambir (80 ton/bulan), cengkeh (20 ton/bulan), kapulaga (20 ton/bulan), pala (20 ton/bulan). Komoditi CV. ABC dipasarkan ke negara-negara Asia Selatan seperti India, Pakistan, Bangladesh, atau Nepal

Salah satu kegiatan penting dalam persiapan ekspor biji pinang belah adalah sortasi. Kegiatan sortasi akan mengelompokkan mutu biji pinang belah menjadi good quality (kualitas baik) atau lalee quality (kualitas jelek) [2]. Produktivitas kegiatan sortasi biji pinang diukur berdasarkan kualitas dan kuantitas produk. Perusahaan memberikan target kepada tenaga kerja dalam menyortir pinang yakni sebanyak 6-7 karung biji pinang good quality (satu karung @90 kg).Jumlah (kuantitas) 
barang yang dihasilkan dipengaruhi oleh mutu yang disortir. Kondisi ini didapatkan dari kegiatan teknis sortasi di lapangan dan waktu kerja efektif perusahaan. Jumlah kerja efektif perusahaan yakni 7 jam/hari [2].

Jika mutu biji pinang tidak bagus maka kemungkinan karyawan sortir akan mendapatkan sedikit sortiran yang bagus dan nantinya juga akan mempengaruhi upah yang akan di terima. Pinang yang disortir terdiri dari pinang bagus (good quality) dan tidak bagus (lalee quality). Sejauh ini tenaga kerja sortasi mencapai target kerja yang dibebankan. Secara rata rata produktivitas tenaga kerja dalam sortasi jika mutu barang yang disortir bagus yakni 4-5 karung biji pinang good quality (satu karung @ $90 \mathrm{~kg}$ ), dan lalee quality yang didapat 1-2 karung (satu karung@80kg) [2]. Jika mutu pinang yang disortir kurang bagus maka mereka akan mendapatkan pinang good quality 2-3 karung dan 1-2 karung lalee quality [2]

Dalam menghadapi persaingan dunia usaha dan peningkatan berkelanjutan $\mathrm{CV}$. $\mathrm{ABC}$ dituntut untuk dapat memaksimalkan semua sumber daya yang dimiliki. Peranan sumber daya manusia dirasakan penting dan merupakan ujung tombak dalam meraih keunggulan kompetitif. Banyak perusahaan ekspor selain CV.ABC yang secara kompetetif menjaga kualitas dan kuantitas biji pinang untuk diekspor. Untuk mencapai hasil kerja yang optimal maka perbaikan kinerja tenaga kerja merupakan salah satu aspek yang harus diperhatikan oleh perusahaan. Banyak hal yang harus dilakukan perusahaan untuk perbaikan dan peningkatan kinerja. Perbaikan kinerja dapat dilakukan dengan mengetahui faktor-faktor yang menyebabkan naik atau turunnya kinerja yang dimiliki tenaga kerja, kemudian mengevaluasinya.

Tujuan dari penelitian ini adalah mengetahui pengaruh motivasi, lingkungan kerja, gaji, beban kerja dan usia terhadap kinerja tenaga kerja bagian sortasi biji pinang CV. ABC serta menghasilkan rekomendasi untuk peningkatan kinerja tenaga kerja berdasarkan faktorfaktor yang berpengaruh terhadap tenaga kerja bagian sortasi biji pinang CV. ABC. Metode penelitian yang digunakan dalam penelitian ini adalah metode survei yang menggunakan kuisioner sebagai pengumpul data pokok. Faktor-faktor berpengaruh dalam kinerja tenaga sortasi didapatkan dari literatur, selanjutnya diberikan penilaian terhadap kuisioner oleh responden dengan menggunakan Skala Likert. Jawaban setiap item instrumen yang menggunakan skala Likert mempunyai gradasi dari sangat positif sampai sangat negatif, dengan interval nilai 5 hingga 1 . Setelah faktor-faktor kinerja tenaga sortasi teridentifikasi, diberikan usulan terhadap kinerja tenaga sortasi. Analisis pengolahan data menggunakan regresi linear berganda.

\section{METODOLOGI}

Penelitian ini dilaksanakan pada bulan April-Mei 2015. Penelitian dilaksanakan di Perusahaan Ekspor Hasil Bumi dan Rempah-Rempah CV. ABC Jl. Adinegoro No. 38 Simp. Lalang Padang, Sumatera Barat. Alat yang digunakan dalam penelitian adalah borang kuesioner dan alat tulis untuk mendapatkan data kuisioner yang diperlukan selama penelitian. Sementara untuk pengamatan ergonomi lingkungan kerja digunakan alat thermohygrometer, lux meter, sound level meter dan alat tulis. Pengolahan data kuisioner menggunakan software SPSS 17.0 (Statistical Package for Social Science). SPSS digunakan untuk menganalisis suatu riset ilmiah yang bersifat sosial.

\section{Populasi, Sampel dan Metode Pengambilan Sampel}

Populasi (N) dalam penelitian ini adalah seluruh karyawan sortasi biji pinang $\mathrm{CV}$. ABC yang berjumlah 50 orang. Penentuan jumlah sampel yang dijadikan sebagai responden dalam penelitian ini adalah $\geq 25 \%$ dari populasi yang ada [3].

Teknik pengambilan sampel yang akan digunakan dalam penelitian ini adalah metode stratified random sampling, dengan pengertian bahwa populasi dalam penelitian ini bersifat heterogen, dengan langkah mengelompokkan populasi menjadi sub populasi berdasarkan pada karakteristik tertentu, sehingga pada setiap sub populasinya mempunyai anggota sampel yang homogen. Kemudian dari setiap sub populasi diambil secara acak untuk setiap anggota sampelnya sesuai dengan ciri-ciri karakteristik sampelnya, seperti jenis kelamin, usia, pendidikan dan lama bekerja.

\section{Teknik Pengumpulan Data}

Teknik pengumpulan data yang digunakan adalah:

1. Pengamatan (Observation), yaitu pengamatan atas rutinitas pekerjaan para Tenaga kerja sortasi biji pinang CV. ABC pada saat jam kerja dan di lokasi tempat para tenaga kerja melaksanakan tugasnya. Pengukuran data lingkungan kerja (suhu, temperatur, pencahayaan, kebisingan) dilakukan pada pukul 07.00 dan 09.00 WIB dan siang hari pada pukul 11.00 dan 13.00 WIB [4].

2. Daftar pertanyaan (Questionnaire), diberikan kepada tenaga kerja sortasi biji pinang $\mathrm{CV}$. ABC yang dijadikan sampel.

3. Studi dokumentasi, mengumpulkan dan mempelajari dokumen-dokumen yang relevan untuk mendukung data penelitian yang diperoleh dari CV. ABC. 


\section{Identifikasi dan Definisi Operasional Variabel}

Variabel penelitian terdiri dari satu variabel dependen yaitu Produktivitas Tenaga Kerja (Y) dan variabel independen yaitu: Motivasi (X1), Lingkungan Kerja (X2), Gaji (X3), Beban Kerja (X4), dan Usia (X5). Pengukuran variabel yang digunakan dalam penelitian ini adalah dengan menggunakan skala Likert. Menurut Sugiyono [5], skala Likert digunakan untuk mengukur sikap, pendapat, dan persepsi seseorang atau sekelompok orang tentang fenomena sosial. Dalam penelitian fenomena sosial ini telah ditetapkan secara spesifik oleh peneliti, yang selanjutnya disebut sebagai variabel penelitian. Jawaban setiap item instrumen yang menggunakan skala Likert mempunyai gradasi dari sangat positif sampai sangat negatif, yang dapat berupa kata-kata antara lain:

$$
\begin{aligned}
& \text { SB }=\text { Sangat Baik } \\
& \text { Bk }=\text { Baik } \\
& \text { KB }=\text { Kurang Baik } \\
& \text { TB }=\text { Tidak Baik } \\
& \text { STB }=\text { Sangat Tidak Baik }
\end{aligned}
$$

\section{Pengujian Instrumen Data \\ Uji Validitas}

Arikunto [6] mengemukakan tujuan uji coba adalah diperolehnya informasi mengenai kualitas instrumen yang digunakan valid. Pengujian data dengan uji validitas ini dilakukan dengan langkah mengkorelasikan antara skor yang telah diperoleh untuk masing-masing pertanyaan (kuisioner) terhadap koresponden dengan skor total. Pengujian dengan uji validitas ini dilakukan dengan menggunakan taraf signifikansi sebesar 0,05 (5\%). Uji validitas akan diujikan dengan menggunakan teknik "pearson's product moment correlation",

\section{Uji Reliabilitas}

Jika alat ukur sudah dinyatakan valid maka selanjutnya reliabilitas alat ukur tersebut diuji. Menurut [7] mengatakan reliabilitas adalah suatu nilai yang menunjukkan konsistensi suatu alat pengukur di dalam mengukur gejala yang sama. Setiap alat pengukur seharusnya memiliki kemampuan untuk memberikan hasil pengukuran yang konsisten. Uji reliabilitas akan diujikan dengan menggunakan teknik "alpha", [8].

\section{Uji Heteroskedastisitas}

Uji heteroskedastisitas dilakukan untuk menguji apakah dalam sebuah model regresi terjadi ketidaksamaan varians residual dari satu pengamatan ke pengamatan yang lain tetap. Cara untuk mengetahui ada tidaknya gejala Heteroskedatisitas yaitu dengan metode grafik. Pada metode grafik, jika titik-titik menyebar diatas dan dibawah angka 0 pada sumbu $\mathrm{Y}$ tanpa membentuk pola tertentu, maka tidak terjadi heteroskedastisitas.

\section{Metode Analisis Data}

Analisis data yang digunakan dalam permasalahan kedua ini adalah Analisis Regresi Linear Berganda yang digunakan untuk mengetahui pengaruh variabel independen terhadap variabel dependen. Pengolahan data menggunakan software SPSS (Statistical Package for Social Science). Persamaan model regresi berganda menurut [5] adalah sebagai berikut:

$\hat{Y}=\alpha+\beta 1 X 1+\beta 2 X 2+\beta 3 X 3+\beta 4 X 4+\beta 5 X 5+\varepsilon$

Ket :

$\hat{Y}=$ Produktivitas Tenaga Kerja

$\alpha=$ Intercept $/$ konstanta

$1 \beta, 2 \beta, \beta 3, \beta 4, \beta 5=$ Koefisien regresi

$\mathrm{X} 1$ = Motivasi

$\mathrm{X} 2$ = Lingkungan kerja

$\mathrm{X} 3$ = Gaji

$\mathrm{X} 4$ = Beban Kerja

$\mathrm{X} 5$ = Usia

$\varepsilon=$ Variabel pengganggu

Pengaruh variabel independen terhadap variabel dependen diuji dengan tingkat kepercayaan $95 \%$ atau $\alpha$ $=5 \%$.

\section{Uji F}

Digunakan untuk menguji apakah variabel independen (motivasi, lingkungan kerja, gaji, beban kerja) secara bersama-sama dapat menjelaskan variabel dependen (kinerja) secara signifikan.

\section{Uji t}

Digunakan untuk menguji apakah variabel independen (motivasi, lingkungan kerja, gaji, beban kerja) secara parsial dapat menjelaskan variabel dependen (kinerja).

\section{Uji Normalitas}

Uji Normalitas dilakukan untuk mengetahui apakah dalam model regresi, variabel pengganggu atau residual memiliki distribusi normal. Dalam uji t dan uji $\mathrm{F}$ diasumsikan bahwa nilai residual mengikuti distribusi normal. Oleh sebab itu Santoso [9], menyatakan "Untuk mengetahui apakah data terdistribusi normal atau mendekati normal atau bias dianggap normal, jika bias maka akan dilakukan uji Normality Plot, yaitu suatu pengujian dengan menggunakan Grafik PP-Plot”.

\section{Uji Multikolinearitas}

Uji ini bertujuan untuk menguji apakah dalam model regresi ditemukan adanya korelasi antar variabel bebas. Model regresi yang baik seharusnya tidak terjadi korelasi di antara variabel bebasnya. Menurut [10], bahwa jika variabel independen saling berkorelasi, maka variabel ini tidak ortogonal. Variabel ortogonal adalah variabel independen yang nilai korelasi antar 
sesama variabel independen sama dengan nol. Untuk mendeteksi ada tidaknya multikolinearitas di dalam model regresi dapat dilihat dari nilai tolerance dan lawannya Variance Inflation Factor (VIF), jika nilai tolerance $<0,10$ atau nilai VIF $>10$ berarti terdapat Multikolinearitas.

\section{Kajian Ergonomi Lingkungan}

Kajian Ergonomi Lingkungan bertujuan untuk menganalis kondisi lingkungan kerja sortasi pinang CV. ABC yang menjadi faktor variabel independen yang diteliti. Teknis pengukuran kajian ergonomi lingkungan sebagai berikut:

\section{Pengukuran Suhu dan Kelembaban Udara}

Pengukuran suhu dan kelembaban udara dilakukan dengan menggunakan metode pembacaan langsung dengan alat Termohigrometer. Pengukuran suhu dan kelembaban dilakukan di tiga titik yaitu kiri, tengah dan kanan tempat kerja tenaga sortasi (lapangan), kemudian hasilnya dirata-rata [4].

\section{Pengukuran kebisingan}

Pada prinsip kerjanya Sound Level Meter diarahkan ke sumber suara, setinggi telinga, agar dapat menangkap kebisingan yang tercipta. Pengukuran kebisingan dilakukan di tiga titik yaitu kiri, tengah dan kanan tempat kerja tenaga sortasi kemudian hasilnya diratarata [4]

\section{Pengukuran Pencahayaan}

Alat yang digunakan untuk mengukur intensitas cahaya adalah Light meter. Untuk mengukur pencahayaan digunakan teknik pengukuran Local Lighting [4].

\section{HASIL DAN PEMBAHASAN}

\section{Uji Validitas}

Uji validitas diarahkan untuk menguji ketepatan instrumen dalam mengukur variabel laten yang ingin diketahui perilakunya [5]. Uji validitas dilakukan dengan menggunakan software SPSS versi 17.0. Hasil uji validitas dari penelitian dapat dilihat pada Tabel 1.

Tabel 1. Hasil Uji Validitas Data

Case Processing Summary

\begin{tabular}{llrr}
\hline & & $\mathrm{N}$ & $\%$ \\
\hline Cases & Valid & 17 & 100.0 \\
& Excluded $^{\mathrm{a}}$ & 0 & .0 \\
& Total & 17 & 100.0 \\
\hline $\begin{array}{l}\text { a. Listwise deletion based on all variables in the } \\
\text { procedure. }\end{array}$
\end{tabular}

Keluaran (output) pada Tabel 1 menjelaskan tentang jumlah data yang valid untuk diproses dan data yang dikeluarkan. Dari Tabel 1 tersebut dapat dilihat bahwa data atau case yang valid berjumlah 17 dengan persentase $100 \%$ dan tidak ada data yang dikeluarkan.

\section{Uji Reliabilitas}

Uji reliab digunakan untuk mengetahui konsistensi alat ukur, apakah alat pengukur yang digunakan dapat diandalkan dan tetap konsisten jika pengukuran tersebut diulang. Adapun uji statistik yang digunakan untuk menguji reliabilitas adalah Uji Statistik Cronbach Alpha. Dalam pengujian reliabilitas menggunakan SPSS 17.0 Langkah yang ditempuh yaitu sama dengan langkah pengujian validitas karena output keduanya bersamaan muncul. Reliabilitas suatu konstruksi variabel dikatakan baik jika memiliki nilai Cronbach's Alpha $>0,6$.

Dari hasil perhitungan dengan SPSS 17.0 nilai 0,847 Cronbach's Alpha menjelaskan bahwa data yang diuji reliabel dan baik. Setelah data diuji validitas dan reliabilitasnya maka langkah selanjutnya data yang telah valid dan reliabel pada penelitian ini diolah dengan menggunakan perhitungan regresi linier berganda.

\section{Pengujian Persyaratan Regresi Linear Berganda}

Analisis regresi digunakan untuk memprediksi seberapa jauh perubahan nilai variabel terikat, bila nilai variabel bebas dimanipulasi/dirubah atau dinaik-turunkan [11]. Manfaat dari hasil analisis regresi adalah untuk membuat keputusan apakah naik dan menurunnya variabel dependen dapat dilakukan melalui peningkatan variabel independen atau tidak.

Analisis regresi berganda digunakan oleh peneliti, untuk meramalkan bagaimana keadaan (naik turunnya) variabel terikat (kriterium), bila dua atau lebih variabel bebas sebagai faktor prediktor dimanipulasi (dinaik turunkan nilainya). Analisis regresi ganda akan dilakukan bila jumlah variabel independennya minimal 2.

Persamaan garis regresi ganda adalah sebagai berikut [11]:

$\hat{\mathrm{Y}}=\mathrm{a}+\mathrm{b} 1 \mathrm{X}+\mathrm{b} 2 \mathrm{X}+\mathrm{b} 3 \mathrm{X}+\ldots . . \mathrm{b} 4 \mathrm{X}$

Dalam penelitian ini terdapat variabel bebas dan variabel terikat, sebagai berikut:

- Variabel bebas yaitu:

$\mathrm{X} 1$ = Motivasi kerja

$\mathrm{X} 2$ = Lingkungan kerja

$\mathrm{X} 3$ = Gaji

$\mathrm{X} 4$ = Beban kerja

$\mathrm{X} 5$ = Usia

Variabel terikat (Y), yaitu Kinerja tenaga kerja 


\section{Uji Asumsi Klasik}

Uji asumsi klasik ini dilakukan karena dalam model regresi perlu memperhatikan adanya penyimpanganpenyimpangan atas asumsi klasik, karena pada hakekatnya jika asumsi klasik tidak dipenuhi maka variabel variabel yang menjelaskan akan menjadi tidak efisien. Pada penelitian ini dilakukan beberapa uji asumsi klasik terhadap model regresi yang telah diolah dengan menggunakan program SPSS [9] yang meliputi:

\section{Uji Normalitas}

Uji normalitas menguji apakah dalam model regresi, variabel independen dan variabel dependen, keduanya terdistribusikan secara normal atau tidak, maka pengujian ini menggunakan bantuan komputer program SPSS versi 17.0.

Normalitas data dalam penelitian dilihat dengan cara memperhatikan penyebaran data (titik) pada Normal PPlot of Regression Standardized Residual dari variabel terikat dan Histogram Residual. Grafik Probability Normal dan Histogram Residual dapat dilihat pada Gambar 1 dan 2.

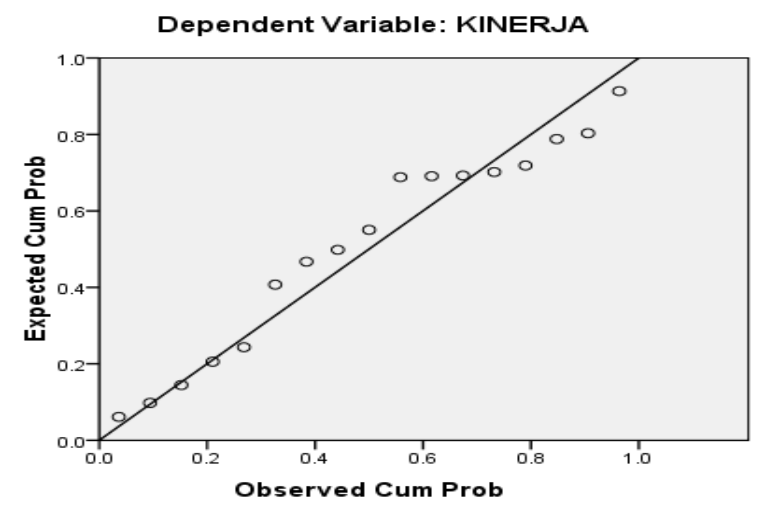

Gambar 1. Grafik Probability Normal

Persyaratan dari uji normalitas data adalah jika data menyebar di sekitar garis diagonal dan mengikuti arah garis diagonal, maka model regresi memenuhi asumsi normalitas [12]. Jika data menyebar jauh dari garis diagonal atau tidak mengikuti garis diagonal, maka model regresi tidak memenuhi asumsi normalitas [12]. Berdasarkan hasil pengolahan data dalam penelitian ini maka didapatkan hasil bahwa semua data berdistribusi secara normal dan tidak terjadi penyimpangan, sehingga data yang dikumpulkan dapat diproses dengan metodemetode selanjutnya. Hal ini dapat dibuktikan dengan memperhatikan sebaran data yang menyebar disekitar garis diagonal pada "Normal P-Plot of Regresion Standardized Residual". Model regresi berdistribusi normal juga dapat dilihat dari histogram residualnya.

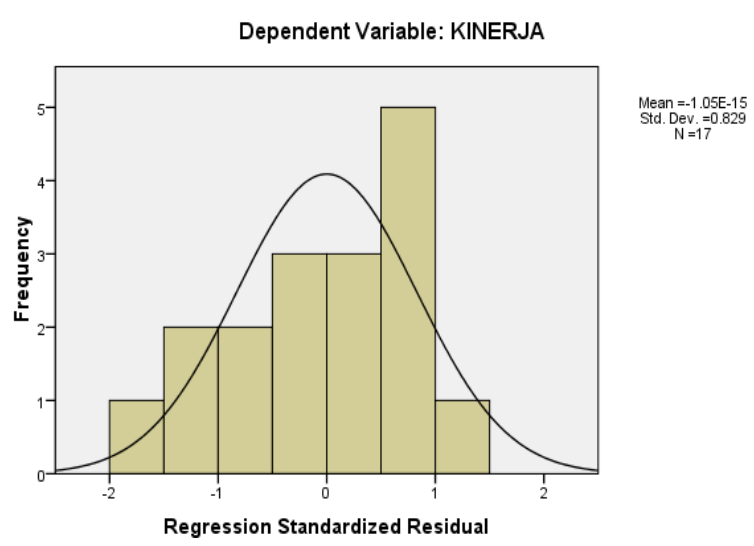

Gambar 2. Histogram Residual

Pada Gambar 2 histogram residual berbentuk lonceng. Asumsi normalitas terpenuhi jika histogram mendekati bentuk lonceng [13].

\section{Uji Heteroskedastisitas}

Untuk melihat varian yang tidak sama pada semua pengamatan di dalam model regresi (Heteroskedastisitas) dapat dilihat pada Output Scatterplot

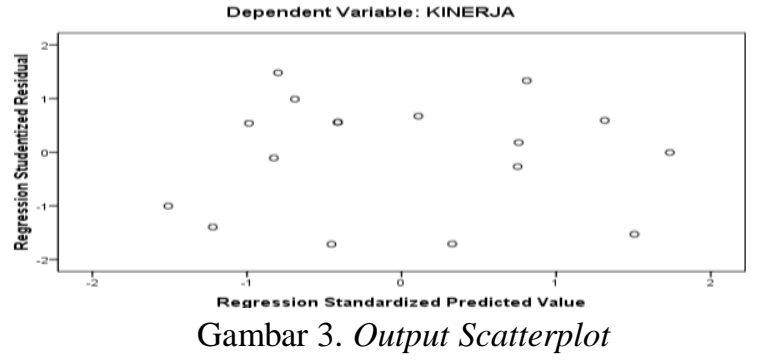

Dari Gambar 3 dapat diketahui bahwa titik-titik tidak membentuk pola yang jelas dan berada di atas dan di bawah angka 0 sumbu Y. Jadi, dapat disimpulkan tidak terjadi Heteroskedastisitas dalam model regresi.

\section{Uji Multikolinieritas}

Uji multikolinieritas dilakukan untuk menguji apakah pada model regresi ditemukan adanya korelasi antar variabel independen. Jika terjadi korelasi, maka dinamakan terdapat problem Multikolinieritas. Pengujian ada tidaknya gejala multikolinearitas dilakukan dengan memperhatikan nilai VIF (Variance Inflation Factor) dan tolerance variabel independen. Nilai tolerance dan VIF dari variabel independen penelitian dapat dilihat pada Tabel 2. 
Tabel 2. Nilai Tolerance dan VIF Variabel Independen

\begin{tabular}{lcc}
\hline \multicolumn{1}{c}{ Variabel } & Tolerance & $\begin{array}{c}\text { Variance } \\
\text { Inflation } \\
\text { Factor (VIF) }\end{array}$ \\
\hline Motivasi Kerja & 0,346 & 2,894 \\
Lingkungan Kerja & 0,544 & 1,838 \\
Gaji & 0,393 & 2,543 \\
Beban Kerja & 0,733 & 1,364 \\
Usia & 0,636 & 1,572 \\
\hline
\end{tabular}

Dari ketentuan yang ada bahwa jika nilai VIF $<10$ dan tolerance $>0,10$ maka tidak terjadi gejala multikolinearitas dan nilai-nilai yang tersaji pada Tabel 2 adalah sesuai dengan ketetapan nilai VIF dan tolerance. Hasil analisis pada Tabel 2 diketahui nilai toleransi semua variabel independen (Motivasi Kerja, Lingkungan Kerja, Gaji, Beban Kerja dan Usia) lebih dari 0.10 dan nilai VIF kurang dari 10, maka dapat disimpulkan bahwa variabel independennya tidak terjadi multikolinieritas sehingga model tersebut telah memenuhi syarat asumsi klasik dalam analisis regresi. Model regresi yang baik seharusnya tidak terjadi korelasi diantara variabel independen [14].

\section{Uji Statistik}

\section{Uji Koefisien Determinasi $\left(\mathbf{R}^{\mathbf{2}}\right)$}

Nilai koefisien determinasi $\left(\mathrm{R}^{2}\right)$ mencerminkan seberapa besar variasi dari variabel terikat $\mathrm{Y}$ dapat diterangkan oleh variabel bebas $\mathrm{X}$, atau dengan kata lain seberapa besar X memberikan kontribusi terhadap Y [11]. Koefisien determinasi digunakan untuk menguji goodness-fit dari model regresi yang dapat lihat dari nilai R Square. Nilai $\mathrm{R}^{2}$ dapat dilihat pada Tabel 3

Tabel 3. Hasil Uji Regresi (Koefisien Determinasi)

Model Summary

\begin{tabular}{|c|c|c|c|c|}
\hline Model & $\mathrm{R}$ & $\begin{array}{c}R \\
\text { Square }\end{array}$ & $\begin{array}{c}\text { Adjusted } R \\
\text { Square }\end{array}$ & $\begin{array}{c}\text { Std. Error } \\
\text { of the } \\
\text { Estimate }\end{array}$ \\
\hline 1 & $0,837^{\mathrm{a}}$ & 0,700 & 0,564 & 2,707 \\
\hline a. & \multicolumn{4}{|c|}{$\begin{array}{l}\text { Predictors : (Constant), USIA, } \\
\text { BEBAN_KERJA, GAJI, } \\
\text { LINGKUNGAN_KERJA, } \\
\text { MOTIVASI_KERJA }\end{array}$} \\
\hline
\end{tabular}

Untuk mengetahui tingkat kinerja karyawan sortasi CV. $\mathrm{ABC}$ yang dipengaruhi oleh beberapa faktor antara lain yaitu (Motivasi Kerja, Lingkungan Kerja, Gaji, Beban Kerja dan Usia) dapat dilihat melalui besarnya koefisien determinasi. Pada Tabel 3 nilai R Square adalah 0,700. Hal ini dapat diartikan bahwa sebesar $70 \%$ dari kinerja tenaga kerja sortasi CV. ABC dapat dijelaskan oleh motivasi kerja (X1), lingkungan kerja (X2), gaji (X3), beban kerja (X4) dan usia (X5), sedangkan sisanya 30\% diterangkan oleh faktor lain yang tidak diteliti. Koefisien determinasi ini dimaksudkan untuk mengetahui seberapa besar kemampuan model regresi linear berganda menjelaskan perubahan nilai variabel dependennya [14].

\section{Uji Simultan (Uji F)}

Uji-F digunakan untuk menguji koefisien regresi secara bersama-sama. Hasil uji $\mathrm{F}$ pada penelitian ini dapat dilihat pada Tabel 4.

Tabel 4. Hasil Uji F

\begin{tabular}{lrrrrr}
\multicolumn{5}{c}{ ANOVA $^{\mathbf{b}}$} \\
\hline Model & $\begin{array}{c}\text { Sum of } \\
\text { Squares }\end{array}$ & df & $\begin{array}{c}\text { Mean } \\
\text { Square }\end{array}$ & F & Sig. \\
\hline 1 Regression & 188.342 & 5 & 37,668 & 5,141 & $0,011^{\text {a }}$ \\
Residual & 80.600 & 11 & 7,327 & \\
Total & 268.941 & 16 & & \\
\hline a. & Predictors: & (Constant), & USIA, \\
LINGKUNGAN_KERJA, & BEBAN_KERJA, & GAJI, \\
MOTIVAS_KERJA & & &
\end{tabular}

b. Dependent Variable : KINERJA

Langkah-langkah yang dilakukan dalam menganalisis hasil uji simultan (uji F), yaitu:

1. Merumuskan hipotesis

Ho = Motivasi kerja, lingkungan kerja, gaji, beban kerja dan usia secara bersama-sama tidak berpengaruh signifikan terhadap kinerja karyawan sortasi.

$\mathrm{H} 1$ = Motivasi kerja, lingkungan kerja, gaji, beban kerja dan usia secara secara bersama-sama berpengaruh signifikan terhadap kinerja karyawan sortasi.

2. Menentukan nilai kritis atau $\mathrm{F}$ tabel

Dari tabel F diperoleh $\mathrm{F}(\mathrm{dfl}=5 ;$ df $2=11 ; \alpha=0,05)$ $=3,20$

3. Menentukan F hitung:

Dari Tabel 4 di atas diperoleh $\mathrm{F}$ hitung $=5,141$

4. Mengambil keputusan:

a. Membandingkan $\mathrm{F}$ hitung dengan $\mathrm{F}$ tabel. Oleh karena 5,141 > 3,20, maka H0 ditolak dan H1 diterima.

b. Berdasarkan probabilitas

Dari Tabel 4 diketahui probabilitas adalah 0,011 atau lebih kecil dari 0,05, maka $\mathrm{H} 0$ ditolak dan $\mathrm{H} 1$ diterima. Angka signifikansi sebesar 0,011 < 0,05. Atas dasar perbandingan tersebut, maka Ho ditolak atau berarti variabel motivasi kerja (X1), lingkungan kerja kerja (X2), gaji (X3), beban kerja (X4) dan 
usia (X5) mempunyai pengaruh yang signifikan secara bersama-sama terhadap variabel kinerja.

5. Membuat Kesimpulan

Dari hasil uji $\mathrm{F}$ pada penelitian ini didapatkan nilai $\mathrm{F}$ hitung sebesar 5,141 dan angka signifikansi sebesar 0,011 dengan tingkat signifikansi 95\% $(\alpha=0,05)$. Berdasarkan hasil uji $\mathrm{F}$ di atas, diketahui bahwa $\mathrm{H} 0$ ditolak dan $\mathrm{H} 1$ diterima. Hal ini berarti bahwa motivasi kerja, lingkungan kerja, gaji, beban kerja dan usia secara bersama-sama berpengaruh signifikan terhadap kinerja karyawan sortasi.

\section{Uji Signifikan Parameter Parsial (Uji t)}

Uji- $\mathrm{t}$ digunakan untuk menguji koefisien regresi berganda secara parsial (individu). Pada uji statistik secara parsial dengan nilai t kritis (critical value) pada $\mathrm{df}=(\mathrm{n}-\mathrm{k})$, dimana $\mathrm{n}$ adalah jumlah sampel dan $\mathrm{k}$ adalah jumlah variabel independen termasuk konstanta. Hasil uji t pada penelitian ini dapat dilihat pada Tabel 5 . Untuk menguji koefisian regresi parsial secara variabel bebas akan diuji dilakukan langkah sebagai berikut:

Tabel 5. Hasil Uji t

Coefficients $^{\mathrm{a}}$

\begin{tabular}{|c|c|c|c|c|c|c|c|}
\hline \multirow{2}{*}{ Model } & \multicolumn{2}{|c|}{$\begin{array}{l}\text { Unstandardized } \\
\text { Coefficients }\end{array}$} & \multirow{2}{*}{$\begin{array}{c}\text { Standardized } \\
\text { Coefficients } \\
\text { Beta }\end{array}$} & \multirow[t]{2}{*}{$\mathrm{T}$} & \multirow[t]{2}{*}{ Sig. } & \multicolumn{2}{|c|}{ Collinearity Statistics } \\
\hline & $\mathrm{B}$ & $\begin{array}{c}\text { Std. } \\
\text { Error }\end{array}$ & & & & Tolerance & VIF \\
\hline 1 (Constant) & $-4,640$ & 10.235 & & $-0,453$ & 0,659 & & \\
\hline MOTIVASI_KERJA & 0,210 & 0,209 & 0,282 & 1,005 & 0,337 & 0,346 & 2,894 \\
\hline LINGKUNGAN_KERJA & 0,089 & 0,235 & 0,085 & 0,379 & 0,712 & 0,544 & 1,838 \\
\hline GAJI & 0,080 & 0,234 & 0,089 & 0,340 & 0,740 & 0,393 & 2,543 \\
\hline BEBAN_KERJA & $-0,070$ & 0,184 & $-0,073$ & $-0,380$ & 0,711 & 0,733 & 1,364 \\
\hline USIA & 0,813 & 0,293 & 0,57 & 2,77 & 0,0 & 0,636 & 1,572 \\
\hline
\end{tabular}

Dari hasil uji-t pada penelitian ini untuk nilai variabel (X1-X4) t. hitung < t. tabel sebesar 2,201 dan angka signifikasi > 0,05. Hal ini berarti $\mathrm{H} 0$ diterima dan H1 ditolak. Hanya pada variabel X5 yang sesuai dengan aturan regresi berganda. Pada variabel X5 nilai t. hitung $2,772>2,201$ dan angka signifikansi $<0,05$. Ini berarti H0 ditolak dan H1 diterima. Variabel Usia (X5) secara parsial berpengaruh terhadap kinerja karyawan sortasi.

Berdasarkan pada Tabel 5 maka didapatkan persamaan regresi linear berganda sebagai berikut:

$\mathrm{Y}=-4,460+0,210 \mathrm{X} 1+0,089 \mathrm{X} 2+0,080 \mathrm{X} 3-0,070$ $\mathrm{X} 4+0,813$ X5 . Persamaan tersebut dijelaskan sebagai berikut:

1. Nilai konstanta pada persamaan tersebut adalah 4,460. Ini berarti jika semua variabel bebas memiliki nilai nol (0) maka nilai variabel terikat adalah 4,460 .

2. Nilai 0,210 pada variabel $X 1$ adalah bernilai positif sehingga dapat dikatakan bahwa semakin tinggi motivasi kerja semakin tinggi kinerja tenaga kerja. Koefisien motivasi kerja berpengaruh positif terhadap kinerja tenaga kerja secara signifikan. Jika realisasi motivasi kerja naik 1 satuan maka variabel Beta (Y) akan naik sebesar 0,210 dengan asumsi bahwa variabel bebas yang lain dari model regresi adalah tetap.
3. Nilai 0,089 pada variabel $\mathrm{X} 2$ adalah bernilai positif sehingga dapat dikatakan bahwa semakin baik lingkungan kerja semakin tinggi kinerja tenaga kerja. Koefisien lingkungan kerja berpengaruh positif terhadap kinerja tenaga kerja secara signifikan. Jika realisasi lingkungan kerja naik 1 satuan maka variabel Beta (Y) akan naik sebesar 0,089 dengan asumsi bahwa variabel bebas yang lain dari model regresi adalah tetap.

4. Nilai 0,080 pada variabel X3 adalah bernilai positif sehingga dapat dikatakan bahwa semakin tinggi gaji semakin tinggi kinerja tenaga kerja. Koefisien gaji berpengaruh positif terhadap kinerja tenaga kerja secara signifikan. Jika realisasi gaji naik 1 satuan maka variabel Beta (Y) akan naik sebesar 0,080 dengan asumsi bahwa variabel bebas yang lain dari model regresi adalah tetap.

5. Nilai $-0,070$ pada variabel $\mathrm{X} 4$ adalah bernilai negatif sehingga dapat dikatakan bahwa semakin rendah beban kerja semakin tinggi kinerja tenaga kerja. Koefisien beban kerja berpengaruh negatif terhadap kinerja tenaga kerja secara signifikan. Jika realisasi beban kerja turun 1 satuan maka variabel Beta (Y) akan naik sebesar 0,070 dengan asumsi bahwa variabel bebas yang lain dari model regresi adalah tetap.

6. Nilai 0,813 pada variabel X5 adalah bernilai positif sehingga dapat dikatakan bahwa semakin tinggi usia 
produktif (15-65 tahun) semakin tinggi kinerja tenaga kerja. Koefisien usia berpengaruh positif terhadap kinerja tenaga kerja secara signifikan. Jika realisasi usia naik 1 satuan maka variabel Beta (Y) akan naik sebesar 0,813 dengan asumsi bahwa variabel bebas yang lain dari model regresi adalah tetap.

\section{Kajian Ergonomi Lingkungan}

Lingkungan adalah semua keadaan yang terdapat disekitar tempat kerja seperti temperatur, kelembaban udara (RH), pencahayaan, kebisingan, getaran mekanis, bau-bauan, warna dan lain-lain [15].

\section{Temperatur}

Temperatur dan kelembaban di CV. ABC diukur dengan thermohygrometer. Dari hasil pengamatan didapatkan suhu rata-rata lingkungan kerja adalah 32,79 $\left({ }^{\circ} \mathrm{C}\right)$. Kondisi ini tidak cocok untuk kenyamanan bekerja orang Indonesia. Suhu untuk nyaman bekerja yaitu sekitar (24-27) ${ }^{\circ} \mathrm{C}$ bagi orang Indonesia [16].

Temperatur efektif yang banyak dikenal dalam psikologi industri didefinisikan sebagai keadaan temperatur dengan kadar air $50 \%$. Keadaan ini tidak mengakibatkan gangguan terhadap prestasi kerja [16]. Hasil penelitian terdahulu menunjukkan bahwa produktivitas kerja manusia mencapai tingkat yang paling tinggi pada temperatur sekitar (24-27) ${ }^{\circ} \mathrm{C}$ [16]. Persyaratan Keputusan Menteri Kesehatan Republik Indonesia Nomor 1405/MENKES/SK/XI/2002 Tentang Persyaratan Kesehatan Lingkungan Kerja Perkantoran Dan Industri, standar suhu adalah suhu $18{ }^{\circ} \mathrm{C}-28{ }^{\circ} \mathrm{C}$ [17]. Bila suhu udara $>28{ }^{\circ} \mathrm{C}$ perlu menggunakan alat penata udara seperti Air Conditioner (AC), kipas angin, dll. Bila suhu udara luar $<18{ }^{\circ} \mathrm{C}$ perlu menggunakan pemanas ruang.

Menurut penelitian untuk berbagai tingkat temperatur akan memberikan pengaruh yang berbeda-beda seperti berikut:

1. Suhu $\pm 49{ }^{\circ} \mathrm{C}$; temperatur yang dapat ditahan sekitar 1 jam, tetapi jauh diatas tingkat kemampuan fisik dan mental.

2. Suhu $\pm 29{ }^{\circ} \mathrm{C}$; aktivitas mental dan daya tanggap mulai menurun dan cenderung untuk membuat kesalahan dalam pekerjaan, serta timbul kelelahan fisik.

3. Suhu $\pm 24^{\circ} \mathrm{C}$; kondisi optimum.

4. Suhu $\pm 10{ }^{\circ} \mathrm{C}$; kekakuan fisik yang ekstrim mulai muncul.

Suhu dingin mengurangi efisiensi dengan keluhan kaku atau kurangnya koordinasi otot. Suhu panas terutama berakibat menurunnya prestasi pikir. Suhu panas

32 Arsil dan Santosa mengurangi kelincahan, memperpanjang waktu reaksi dan waktu pengambilan keputusan, mengganggu kecermatan kerja otak, mengganggu koordinasi syaraf perasa dan motoris, serta memudahkan untuk dirangsang [18].

\section{Kelembaban udara}

Dari hasil pengamatan didapatkan nilai rata-rata kelembaban udara di lingkungan kerja tenaga kerja sortasi CV. ABC adalah 77,14\%. Kondisi ini tidak cocok dengan persyaratan untuk tenaga kerja di Indonesia. Persyaratan Keputusan Menteri Kesehatan Republik Indonesia Nomor 1405/MENKES/SK/XI/2002 Tentang Persyaratan Kesehatan Lingkungan Kerja Perkantoran dan Industri standar kelembaban udara adalah $40 \%-60 \%$.

\section{Kebisingan}

Dari hasil pengamatan didapatkan nilai rata-rata kebisingan lingkungan kerja sortasi pinang CV. ABC sebesar 57,73 dB. Kondisi ini telah sesuai untuk tenaga kerja di Indonesia. Intensitas kebisingan yang dianjurkan berdasarkan Kep. Men. No. 55 tahun 1999 adalah 85 dBA untuk 8 jam kerja [18].

\section{Pencahayaan}

Dari hasil pengamatan didapatkan nilai rata-rata intensitas cahaya lingkungan kerja sortasi pinang CV. Rasdi \& Co sebesar 620 lux. Kondisi ini telah sesuai untuk tenaga kerja di Indonesia. Persyaratan Keputusan Menteri Kesehatan Republik Indonesia Nomor1405/MENKES/SK/XI/2002 Tentang Persyaratan Kesehatan Lingkungan Kerja Perkantoran dan Industri, standar intensitas cahaya di ruang kerja minimal 100 lux. Prinsip penerangan yang baik adalah jumlah dan intensitas penerangan yang diperlukan hendaknya disesuaikan dengan jenis pekerjaan, daya lihat seseorang dan lingkungannya. Pencahayaan yang kurang memadai merupakan beban tambahan bagi pekerja, sehingga dapat menimbulkan gangguan performance (kinerja) kerja yang akhirnya dapat memberikan pengaruh terhadap kesehatan dan keselamatan kerja [18]. Hal ini sangat erat kaitannya dan mutlak harus ada karena berhubungan dengan fungsi indera penglihatan, yang dapat mempengaruhi produktifitas bagi tenaga kerja. Nilai pencahayaan ( $L u x)$ yang terlalu rendah akan berpengaruh terhadap proses akomodasi mata yang terlalu tinggi, sehingga akan berakibat terhadap kerusakan retina pada mata. Cahaya yang terlalu tinggi akan mengakibatkan kenaikan suhu pada ruangan [18].

\section{Keterkaitan Antar Faktor}

Faktor-faktor yang diujikan pada penelitian ini adalah motivasi kerja, lingkungan kerja, gaji, beban kerja dan 
usia yang mampu mempengaruhi tenaga kerja bagian sortasi. Hasil yang diperoleh setelah melakukan pengujian statistik menghasilkan variabel usia (X5) mampu mempengaruhi tenaga kerja bagian sortasi. Diagram sebab-akibat yang ditimbulkan oleh kelima variabel yang digunakan yaitu motivasi kerja, lingkungan kerja, gaji, beban kerja dan usia terhadap tenaga kerja bagian sortasi. Gambar 4 menjelaskan tentang diagram sebab-akibat (fishbone) pada masingmasing variabel yang diteliti.

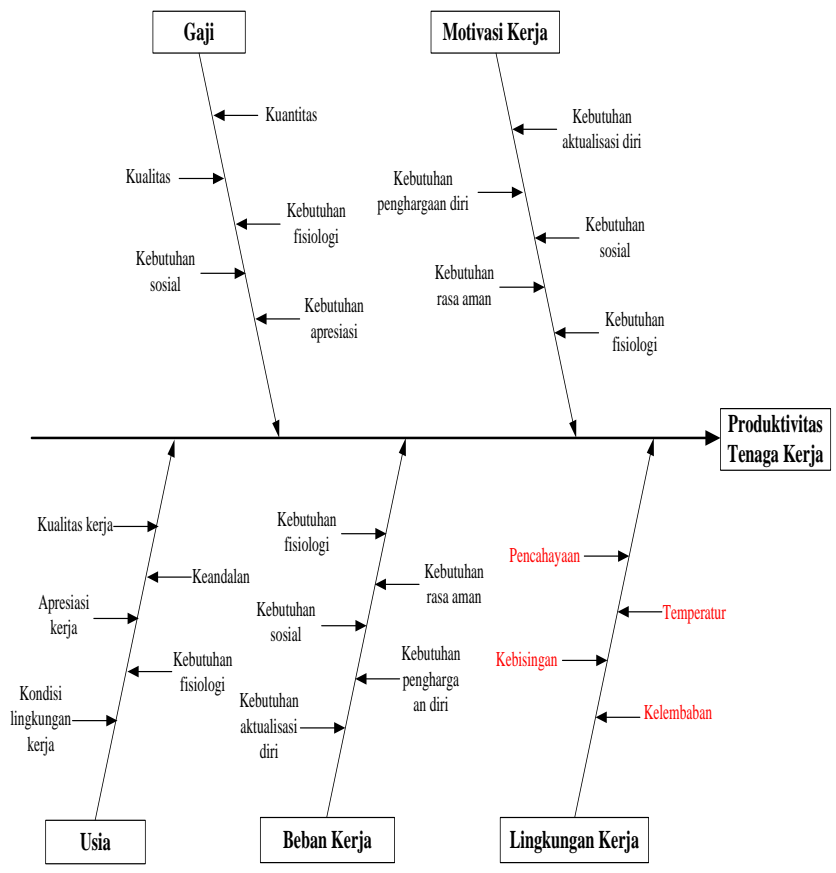

Gambar 4. Diagram Sebab Akibat pada Produktivitas Tenaga Kerja Sortasi Pinang CV. ABC

\section{Hubungan antara Aspek Ergonomis Lingkungan Kerja dengan Hasil Analisis Regresi}

Dari hasil analisis regresi didapatkan bahwa sebesar $70 \%$ dari kinerja tenaga kerja sortasi CV. ABC (Y) dapat dijelaskan oleh motivasi kerja (X1), lingkungan kerja (X2), gaji (X3), beban kerja (X4) dan usia (X5), sedangkan sisanya $30 \%$ diterangkan oleh faktor lain yang tidak diteliti. Variabel lingkungan kerja yang merupakan bagian dari variabel yang diteliti secara spesifik dijelaskan melalui pengamatan analisis ergonomi lingkungan kerja, sehingga secara tepat dapat dijelaskan. Persamaan regresi yang diperoleh adalah $\mathrm{Y}=-4,640+0,210 \mathrm{X} 1+0,089 \mathrm{X} 2+0,080 \mathrm{X} 3-0,070$ $\mathrm{X} 4+0,813 \mathrm{X} 5$. Dari hasil kajian ergonomis lingkungan kerja diketahui nilai aspek intensitas kebisingan dan intensitas pencahayaan telah sesuai dengan aturan di ruang lingkup industri, sementara aspek temperatur dan kelembaban lingkungan kerja tidak sesuai dengan aturan industri sehingga perlu dievaluasi.
Parameter estimasi pengaruh lingkungan kerja pada persamaan bernilai positif. Kondisi lingkungan kerja berpengaruh terhadap kinerja tenaga sortasi, hal ini dibuktikan dengan nilai koefisien (+) pada persamaan regresi, semakin tinggi lingkungan kerja semakin tinggi kinerja tenaga kerja. Jika realisasi lingkungan kerja naik 1 satuan maka variabel bebas (Y) atau kinerja akan naik sebesar 0,089. Berdasarkan kondisi ini diharapkan dapat meningkatkan nilai kondisi lingkungan kerja tenaga sortasi, perusahaan bisa menyediakan ruangan khusus untuk tempat sortir, seperti ruangan tertutup dengan kondisi temperatur dan kelembaban yang lebih baik dan sesuai standar baku industri.

\section{Rekomendasi Perbaikan/Peningkatan Kinerja Tenaga Sortasi}

Aspek penilaian kinerja kerja merupakan penilaian terhadap berbagai aspek yang berkaitan dengan ruang lingkup pekerjaan. Kurangnya perhatian terhadap faktor faktor motivasi kerja, lingkungan kerja, gaji, beban kerja, usia bisa berpengaruh terhadap kinerja kerja tenaga kerja. Maka dari itu perusahaan disarankan untuk selalu mempertahankan penghargaan-penghargaan dan perhatian yang diberikan kepada tenaga kerja. Dari hasil evaluasi kinerja tenaga kerja sortasi pada penelitian ini dapat diajukan beberapa rekomendasi yang bisa jadi bahan pertimbangan perusahaan:

a. Pimpinan dan penanggung jawab kerja lebih memotivasi tenaga kerja dalam bekerja. Dari hasil persamaan regresi linear berganda, nilai 0,210 pada variabel X1 (motivasi kerja) adalah bernilai positif sehingga dapat dikatakan bahwa semakin tinggi motivasi kerja semakin tinggi kinerja tenaga kerja. Koefisien motivasi kerja berpengaruh positif terhadap kinerja tenaga kerja secara signifikan. Jika realisasi motivasi kerja naik 1 satuan maka variabel bebas (Y) atau kinerja akan naik sebesar 0,210 dengan asumsi bahwa variabel bebas yang lain dari model regresi adalah tetap. Motivasi tersebut dapat direalisasikan dengan kebijakan penampahan upah sortir perkgnya, serta jaminan kesehatan dan keselamatan kerja kepada tenaga kerja berdasarkan masa kerjanya.

b. Perusahaan lebih memperhatikan kondisi dan kenyamanan lingkungan kerja, karena setelah dilakukan evaluasi, lingkungan kerja berpengaruh terhadap kinerja tenaga sortasi, hal ini dibuktikan dengan nilai koefisien (+) pada persamaan regresi, semakin tinggi lingkungan kerja semakin tinggi kinerja tenaga kerja. Jika realisasi lingkungan kerja naik 1 satuan maka variabel bebas (Y) atau kinerja akan naik sebesar 0,089. Hasil pengukuran aspek ergonomi lingkungan temperatur dan kelembaban tidak sesuai dengan aturan kerja di ruang lingkup industri, sehingga perlu dievaluasi. 
Perusahaan perlu menyediakan ruangan khusus untuk tempat sortir, seperti ruangan tertutup dengan kondisi temperatur dan kelembaban yang lebih baik. Untuk kenyamanan pekerja sortasi, sebaiknya perusahaan menyediakan meja dan kursi khusus untuk tempat sortir sehingga bisa membuat kegiatan sortasi menjadi lebih baik.

c. Perusahaan diharapkan bisa meningkatkan gaji/upah sortasi biji pinang (Rp 135/kg) yang tergolong kecil dibanding gaji/upah sortasi komoditi lain seperti cassiavera (Rp 175/kg). Gaji merupakan salah satu hal yang meningkatkan gairah semangat bekerja. Nilai 0,080 pada variabel X3 (Gaji) adalah bernilai positif sehingga dapat dikatakan bahwa semakin tinggi gaji semakin tinggi kinerja tenaga kerja. Koefisien gaji berpengaruh positif terhadap kinerja tenaga kerja secara signifikan. Jika realisasi gaji naik 1 satuan maka variabel bebas (Y) atau kinerja akan naik sebesar 0,080 dengan asumsi bahwa variabel bebas yang lain dari model regresi adalah tetap.

d. Perusahaan dapat mengurangi beban kerja tenaga sortasi. Nilai -0,070 pada variabel X4 (beban kerja) adalah bernilai negatif sehingga dapat dikatakan bahwa semakin rendah beban kerja semakin tinggi kinerja tenaga kerja. Jika realisasi beban kerja turun 1 satuan maka variabel bebas (Y) atau kinerja akan naik sebesar 0,070 dengan asumsi bahwa variabel bebas yang lain dari model regresi adalah tetap. Secara rata rata produktivitas tenaga kerja dalam sortasi jika mutu barang yang disortir bagus yakni 4-5 karung biji pinang good quality (satu karung @ $90 \mathrm{~kg}$ ), dan lalee quality yang di dapat 1-2 karung (satu karung @ 80kg), Rasdi (2014). Jika mutu pinang yang disortir kurang bagus maka mereka akan mendapatkan pinang good quality 2-3 karung dan 1-2 karung lalee quality [2].

e. Perusahaan memperhatikan usia produktif tenaga kerja, karena dari hasil analisis diketahui secara parsial faktor usia berpengaruh terhadap kinerja tenaga kerja sortasi. Dari hasil Uji t nilai probabilitas usia berbeda nyata secara statistik. Nilai 0,813 pada variabel X5 adalah bernilai positif sehingga dapat dikatakan bahwa semakin tinggi usia semakin tinggi kinerja tenaga kerja. Koefisien usia berpengaruh positif terhadap kinerja tenaga kerja secara signifikan. Jika realisasi usia naik 1 satuan maka variabel bebas (Y) atau kinerja akan naik sebesar 0,813 dengan asumsi bahwa variabel bebas yang lain dari model regresi adalah tetap.

\section{KESIMPULAN}

Kesimpulan dari penelitian terhadap kinerja karyawan sortasi CV.ABC bisa diidentifikasi melalui persamaan regresi yang diperoleh adalah $\mathrm{Y}=-4,640+0,210 \mathrm{X} 1+$
$0,089 \mathrm{X} 2+0,080 \mathrm{X} 3-0,070 \mathrm{X} 4+0,813 \mathrm{X} 5$. Dari persamaan regresi linear tersebut dapat diketahui bahwa nilai koefisien variabel usia lebih besar dari nilai koefisien variabel bebas lainnya. Nilai koefisien variabel usia sebesar 0,813 . Hal ini berarti variabel usia mempunyai pengaruh yang dominan terhadap kinerja tenaga kerja sortasi CV. ABC. Perusahaan perlu untuk memperhatikan usia produktif tenaga kerja (15-65 tahun). Dari kajian Ergonomi lingkungan kerja diketahui bahwa kondisi temperatur dan kelembaban udara 32,79 $\left({ }^{\circ} \mathrm{C}\right)$ dan $77,14 \%$ di CV.ABC tidak sesuai dengan aturan Keputusan Menteri Kesehatan Republik Indonesia Nomor 1405/MENKES/SK/XI/2002 Tentang Persyaratan Kesehatan Lingkungan Kerja Perkantoran Dan Industri, hanya intensitas kebisingan dan cahaya yang memenuhi standar ketentuan yakni sebesar 57,73 dB dan 620 lux.

Kondisi lingkungan kerja berpengaruh terhadap kinerja tenaga sortasi, hal ini dibuktikan dengan nilai koefisien (+) pada persamaan regresi, semakin tinggi lingkungan kerja semakin tinggi kinerja tenaga kerja. Koefisien lingkungan kerja berpengaruh positif terhadap kinerja tenaga kerja secara signifikan. Jika realisasi lingkungan kerja naik 1 satuan maka variabel bebas (Y) akan naik sebesar 0,089 dengan asumsi bahwa variabel bebas yang lain dari model regresi adalah tetap.

Setelah dilakukan evaluasi terhadap kinerja tenaga sortasi, didapatkan rekomendasi untuk peningkatan kinerja sebagai berikut:

a. Pimpinan dan penanggung jawab kerja lebih memotivasi tenaga kerja dalam bekerja dengan berbagai kebijakan yang representatif terhadap kinerja tenaga sortasi.

b. Perusahaan lebih memperhatikan kondisi dan kenyamanan lingkungan kerja, spesifik terhadap temperatur dan kelembaban udara, karena setelah dilakukan evaluasi, lingkungan kerja berpengaruh terhadap kinerja tenaga sortasi.

c. Perusahaan diharapkan bisa meningkatkan gaji/upah sortasi biji pinang ( Rp 135/kg) yang tergolong kecil dibanding gaji/upah sortasi komoditi lain seperti cassiavera (Rp 175/kg).

d. Perusahaan dapat mengurangi beban kerja tenaga sortasi.

e. Perusahaan memperhatikan usia produktif tenaga kerja, karena dari hasil analisis diketahui secara parsial faktor usia berpengaruh terhadap kinerja tenaga kerja sortasi. 


\section{DAFTAR PUSTAKA}

[1] Direktorat Jenderal Perkebunan. Statistik Perkebunan Indonesia (Periode Tahun 20122014). Kementerian Pertanian Indonesia. Jakarta. 2003

[2] Rasdi. Data Rincian Komoditas Rempah dan Hasil Bumi CV. Rasdi \& Co Tahun 2014. Laporan Produktivitas Ekspor CV. Rasdi \& Co. Padang. 2014

[3] Layli, Maflahah, Faridz. Identifikasi Faktor-faktor yang Berpengaruh Terhadap Tenaga Kerja Bagian Sortasi PT. Kelola Mina Laut Unit Sampang. Prosiding Seminar Nasional APTA - UB. Malang. 2013

[4] Suryaningrat, Ridwan, Soekarno. 2013. Kajian Ergonomi Pada Aspek Lingkungan Kerja Agroindustri: Studi Kasus Pada Pengolahan Karet. Prosiding Seminar Nasional APTA - UB. Malang.

[5] Sugiyono. Metode Penelitian Bisnis. CV. Alfabeta. Bandung. 2007.

[6] Arikunto, S. Prosedur Penelitian: Suatu Pendekatan Praktik. Cetakan Ketigabelas. PT. Rineka Cipta. Jakarta. 2006

[7] Umar, H. Metode Penelitian untuk Skripsi dan Tesis Bisnis. Edisi Baru. PT. Raja Grafindo Persada. Jakarta. 2005

[8] Sekaran, U. Research Methods for Business, A Skill Building (2nd Edition). Jhon Willey n Sons. New York. 1992

[9] Santoso, S. SPSS 10. Mengolah Data Statistik Secara Profesional. PT. Elex Media Komputindo. Jakarta. 2001

[10] Ghozali, I. Aplikasi Analisis Multivariate dengan Program SPSS. B-P UNDIP. Semarang. 2009.

[11] Sugiyono. Metode Penelitian Bisnis (Pendekatan Kuantitatif, Kualitatif dan $R \& D)$ ). CV. Alfabeta. Bandung. 2008.

[12] Priyatno, D. Mandiri Belajar SPSS. Cetakan Pertama. Media Kom. Yogyakarta. 2008

[13] Priyatno, D. 5 Jam Belajar Olah Data dengan SPSS 17. CV. Andi Offset. Yogyakarta. 2009

[14] Pratisto, A. Cara Mudah Mengatasi Masalah Statistik dan Rancangan Percobaan dengan SPSS 12. Gramedia. Jakarta. 2004.

[15] Nurminato, E. Ergonomi Konsep Dasar. Guna Widya. Surabaya. 1998.

[16] Wignjosoebroto, S. Ergonomi, Study Geraka dan Waktu Edisi Pertama. PT. Guna Widya. Jakarta. 1998

[17] Republik Indonesia. Keputusan Menteri Kesehatan Republik

Indonesia Nomor1405/MENKES/SK/XI/2002 Tentang

Persyaratan Kesehatan Lingkungan Kerja
Perkantoran Dan Industri. Departemen Kesehatan R.I. Jakarta. 2002

[18] Suma'mur, P.K. Ergonomi untuk Produktivitas Kerja. CV. Haji Masagung. Jakarta. 1985. 